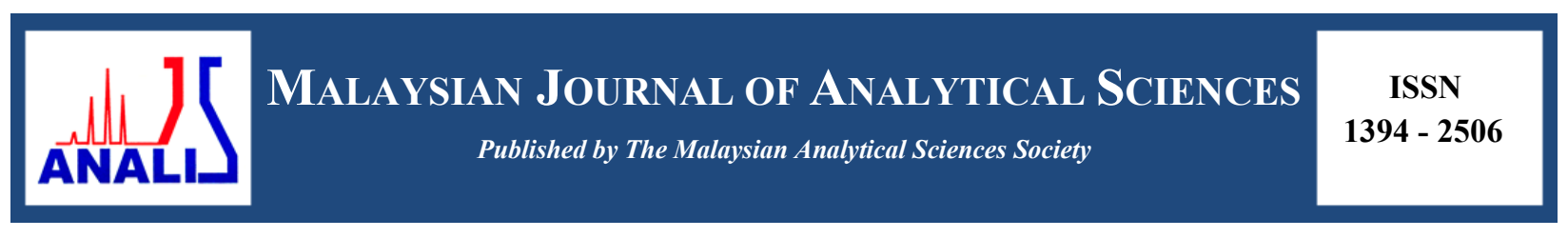

\title{
DETERMINATION OF CAFFEINE IN SURFACE WATER USING SOLID PHASE EXTRACTION AND HIGH PERFOMANCE LIQUID CHROMATOGRAPHY
}

\author{
(Penentuan Kafien di Permukaan Air Mengunakan Pengekstrakan Fasa Pepejal \\ dan Kromatografi Cecair Prestasi Tinggi) \\ Fouad Fadhil Al-Qaim ${ }^{1,2 *}$, Siti Hasmah Jusof ${ }^{1}$, Md Pauzi Abdullah ${ }^{1,3}$, Zainab Haider Mussa ${ }^{1}$, \\ Nurfaizah Abu Tahrim ${ }^{1}$, Wan Mohd Afiq Wan Mohd Khalik ${ }^{1}$, Mohamed Rozali Othman ${ }^{1,3}$

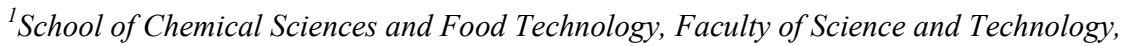 \\ Universiti Kebangsaan Malaysia, 43600 UKM Bangi, Selangor, Malaysia \\ ${ }^{2}$ Chemistry Department, Faculty of Sciences for Women, \\ Babylon University, P.O. Box 4, Hilla, Iraq \\ ${ }^{3}$ Centre for Water Research and Analysis (ALIR), Faculty of Science and Technology, \\ Universiti Kebangsaan Malaysia, 43600 UKM Bangi, Selangor, Malaysia \\ *Corresponding author: fouadalkaim@yahoo.com
}

Received: 9 April 2016; Accepted: 8 October 2016

\begin{abstract}
A new analytical method development based on solid phase extraction (SPE) combined with high performance liquid chromatography (HPLC) was carried out. The optimum working conditions were obtained based on selection of $250 \mathrm{~mL}$ sample loading, $0.25 \mu \mathrm{L}$ methanol as reconstitution solvent, $100 \%$ methanol as mobile phase and $270 \mathrm{~nm}$ as the optimum wavelength. Good linearity was obtained in the range of $0.015-400 \mathrm{mg} / \mathrm{L}$ and the regression coefficient, $\mathrm{R}^{2}$, was 0.995 . Limit of detection and quantification were calculated at $\mathrm{LOD}=0.06 \mu \mathrm{g} / \mathrm{L}$ and $\mathrm{LOQ}=0.2 \mu \mathrm{g} / \mathrm{L}$ respectively. Repeatability and robustness has showed good performance with low relative standard deviation less than $3.29 \%$ and $3.50 \%$ respectively. Time-of-flight mass spectrometry (TOF/MS) instrument was used to confirm that caffeine is definitely present in surface water with level of concentration ranged from 31.7 to $50.1 \mu \mathrm{g} / \mathrm{L}$. All results were analyzed statistically using one-way ANOVA, Tukey with interval confidence $95 \%$ and P-value 0.05 .
\end{abstract}

Keywords: caffeine, stimulant, emerging pollutant, water quality, time of flight/mass spectrometry

\section{Abstrak}

Pembangunan kaedah analisis baru berasaskan pengekstrakan fasa pepejal bersama kromatografi cecair prestasi tinggi (KPCT) telah dijalankan. Kaedah optimum diperolehi berdasarkan tetapan iaitu $250 \mathrm{~mL}$ muatan sampel, $0.25 \mu \mathrm{L}$ metanol sebagai pelarut, $100 \%$ methanol sebagai fasa bergerak dan $270 \mathrm{~nm}$ panjang gelombang yang optimum. Nilai kelinearan baik diperolehi pada julat kepekatan $0.015-400 \mathrm{mg} / \mathrm{L}$ dan nilai pekali regresi, $\mathrm{R}^{2}$ ialah 0.995 . Had pengesanan dan kuantifikasi dihitung masing - masing pada $\mathrm{LOD}=0.06 \mu \mathrm{g} / \mathrm{L}$ and $\mathrm{LOQ}=0.2 \mu \mathrm{g} / \mathrm{L}$. Kebolehulangan dan keteguhan kaedah menunjukkan prestasi baik dengan nilai sisihan piawai relatif yang rendah iaitu masing - masing kurang daripada 3.29\% dan 3.50\%. Spektrometri jisim masa penerbangan (TOF/MS) digunakan untuk mengesahkan kehadiran kafein di permukaan air dengan aras kepekatan antara julat 31.7 hingga $50.1 \mu \mathrm{g} / \mathrm{L}$. Keputusan dianalisa mengunakan pendekatan statistik seperti ANOVA satu hala, Tukey dengan aras keyakinan $95 \%$ and nilai p 0.05 .

Kata kunci: kafein, perangsang, pencemar baru, kualiti air, spektrometri jisim/masa penerbangan 


\section{Introduction}

Caffeine (1,3,7-trimethyxanthine) is a chemical substance widely used in foods, beverages and drugs materials. Caffeine content in chocolate usually ranges between 5 and $35 \mathrm{mg} / \mathrm{oz}$ while in medicine tablet such as Anacin and Excedrin within the range of $30-200 \mathrm{mg}$ concentration per tablet [1]. In human body, only $0.5-10 \%$ of caffeine was required for energy metabolism and the remaining will be excreted [2]. The occurrence of caffeine residue in aquatic environment is related to its presence in food and beverage waste, clinical waste, agricultural and poultry industry either through direct wastewater discharges or disposal of effluent water treatment plants (WWTPs) [3-5]. In groundwater environment, the septic system failure could be the main source of pollution with pharmaceuticals [6]. The residue of caffeine in surface water usually traced at low level concentrations within the range of ng/L to $\mu \mathrm{g} / \mathrm{L}[7,8]$. Nevertheless, it is still threatening to aquatic ecosystem especially living organism likes coral, which is highly sensitive to caffeine [9]. Moreover, this chemical substance posing high solubility and slow rate of degradation, lead to be more persistent in aquatic environments [10]. However, Al-Qaim et al. reported that caffeine can be removed by electrochemical degradation using graphite-poly vinyl chloride as anode as well its by-products which are formed during treatment process [11].

The target drug residues normally occur at low $(\mathrm{ng} / \mathrm{L}$ to $\mu \mathrm{g} / \mathrm{L})$ levels so the pre-concentration is required to increase the detection limit of caffeine. Solid-phase extraction (SPE) is one of the method which is usually chosen $[12,13]$. A part from this, solid-phase microextraction (SPME) [14,15] or liquid-phase microextraction [16] have also been developed for this purpose.

Analysis of caffeine residue in natural waters have been carried in many countries by using various instruments mainly by liquid chromatography $[3,5,17]$ and gas chromatography $[7,18,19]$. However, information of caffeine residue present in Malaysian environment is still limited and unclear. To best of our knowledge, the study on the occurrence of caffeine residue in surface water of Malaysian aquatic environment has not been reported except one study [17] which was conducted by our team. Thus, this study was aimed to extend the optimize work on method development of caffeine residue in water samples and to evaluate the developed method to the analysis of real samples.

\section{Materials and Methods}

Analytical grade standard of caffeine was purchased from Sigma Aldrich (USA). HPLC-grade solvents namely methanol and methyl tert-butyl ether were purchased from Merck (Germany) and J.T. Baker (USA). Solid phase extraction cartridges, Oasis HLB $3 \mathrm{~mL}$ were purchased from Waters (USA). Membrane glass microfiber filters with diameter $47 \mathrm{~mm}$ were purchased from Whatman (UK). Deionized water was obtained by using a Mili-Q Easypure Rodi, Barnstead (USA) instrument.

Caffeine stock solutions were prepared in methanol at $1000 \mathrm{mg} / \mathrm{L}$ level concentrations and stored at $-18{ }^{\circ} \mathrm{C}$. Primary mixture stock solutions were then subsequently diluted for optimization study. A series of stepwise dilution solutions $(0.015-400 \mathrm{mg} / \mathrm{L}, \mathrm{n}=11)$ were used for the construction of external calibration curves in order to determine the unknown concentration of caffeine. Repeatability test was performed at three concentration levels $(50,100$ and $200 \mathrm{mg} / \mathrm{L})$. Limit of detection and quantification of caffeine were obtained based on 3:1 and 10:1 signal to noise ratios respectively. Robustness was performed based on injection volume at three different values $(20,21$ and $22 \mu \mathrm{L})$.

\section{Method extraction}

In general, the method extraction was reported somewhere with a little modification [17], solid phase cartridge initially was conditioned with $2 \mathrm{~mL}$ methyl tert-butyl ether (MTBE), $2 \mathrm{~mL}$ methanol (MeOH) and $2 \mathrm{~mL}$ deionized water. Then required water samples were loaded continuously into the cartridge at flow rate $9.0 \mathrm{~mL} / \mathrm{min}$. Cartridge was then washed with $2 \mathrm{~mL}$ of deionized water before left for dryness approximately half an hour. After that, cartridge was eluted with $5 \mathrm{~mL}$ MTBE, $2 \mathrm{~mL}$ acetone-MeOH (21-9; v/v), and $3 \mathrm{~mL}$ acetone-MeOH (9-21; v/v). Extracted sample was placed under nitrogen stream to complete dryness prior to reconstitute with required volume of methanol. 


\section{HPLC-UV analysis}

High performance liquid chromatography (HPLC PERKIN ELMER 785A) with Chromolith ${ }^{\circledR}$ Performance RP-18e $(4.6 \times 10 \mathrm{~mm}, 5 \mu \mathrm{m})$ column equipped with UV/Vis as detector was used in this study. The optimization work was divided into two portions namely extraction (SPE) and chromatographic performance (HPLC). During the extraction process, effect of changes on variables namely sample volume and re-constitute sample volume were investigated. Meanwhile HPLC performance was tested on optimum condition for variable mobile phase and wavelength. $20 \mu \mathrm{L}$ was injected as a final volume of sample using HPLC. Each sample was injected at least three times to ensure the precision and for other statistical analysis.

\section{TOF/MS analysis}

Mass spectrometry was performed on ESI-TOF instrument (micrOTOF-Q, Bruker /Germany). The results were obtained with the following settings: MS capillary voltages, 4000/3500 (PI/NI); drying-gas flow rate, $8.0 \mathrm{~L} / \mathrm{min}$; drying gas temperature, $190{ }^{\circ} \mathrm{C}$; and nebulizer pressure, 4.0 bar. One adduct ion, namely $[\mathrm{M}+\mathrm{H}]^{+}$was observed for ESI ( + ) analysis in PI mode. Caffeine was acquired using an independent reference spray via the LockSpray interference to ensure accuracy and reproducibility. A mixture of sodium hydroxide and formic acid (FA) was used as the lock mass $\mathrm{m} / \mathrm{z} 90.9766$ to 974.8132 . The accurate mass was calculated using software Daltonics DataAnalysis incorporated in the instrument.

\section{Statistical analysis}

The statistical analysis of variance (one-way ANOVA) was achieved for sample volume, reconstitute volume, wavelength and mobile phase by using Minitab Version 17, Tukey with $\mathrm{P}=0.05$ and $95 \%$ as interval confidence.

\section{Sample collection}

Surface water samples were collected from Alur Ilmu, the storm water channel in Universiti Kebangsaan Malaysia. This channel was connected to the downstream of Langat River. Five stations were chosen during the period of study in November 2014. Samples were collected once from each sampling point. The coordinates for these sampling sites are listed in Table 1. Water sample was collected by using 1 litre glass bottle, capped and transferred directly to laboratory for further analysis.

Table 1. Description of sampling location

\begin{tabular}{lccl}
\hline Station & Longitude & Latitude & Remark \\
\hline S1 & $02^{\circ} 55.336 \mathrm{~N}$ & $101^{\circ} 47.280 \mathrm{E}$ & Upstream, nearby faculty cafeteria \\
S2 & $02^{\circ} 55.393 \mathrm{~N}$ & $101^{\circ} 47.304 \mathrm{E}$ & Drainage after faculty cafeteria \\
S3 & $02^{\circ} 55.534 \mathrm{~N}$ & $101^{\circ} 47.264 \mathrm{E}$ & Drainage before student centre cafeteria \\
S4 & $02^{\circ} 55.579 \mathrm{~N}$ & $101^{\circ} 47.234 \mathrm{E}$ & Drainage after student centre cafeteria \\
S5 & $02^{\circ} 55.727 \mathrm{~N}$ & $101^{\circ} 47.063 \mathrm{E}$ & Downstream, nearby university mosque \\
\hline
\end{tabular}

\section{Effect of sample volume and reconstitution volume on recovery}

This method was compared with other previous methods in terms of mobile phase and retention time. Alvi and Muhammad reported that they used a very complicated mobile phase (15 mM potassium phosphate ( $\mathrm{pH} 3.5)$ and acetonitrile $(83: 17, \mathrm{v} / \mathrm{v})$. The drawback of using buffer solution is to clog the column with the salt of buffer if there is no enough washing. Our study also compared with other previous reported work in terms of solvent consumption [20]. Chowdhury et al., reported that caffeine was separated after 20 min run at $1.0 \mathrm{~mL}$ which means each run could consume $20 \mathrm{~mL}$ [21], compared to our study, only $1.0 \mathrm{~mL}$ was consumed at $0.3 \mathrm{~mL} / \mathrm{min}$ for each run.

The volume of sample was spiked at $100 \mu \mathrm{g} / \mathrm{L}$ of caffeine and three sample volumes (100, 250 and $500 \mathrm{~mL}) \mathrm{were}$ tested. Sample with volume $250 \mathrm{~mL}$ indicated the highest recovery compared to 100 and $500 \mathrm{~mL}$ samples (Figure 
1a). The recovery of caffeine was the lowest when $500 \mathrm{~mL}$ was used. This result is related to the unsuitability of using large volume of sample with the size of the cartridge $(3 \mathrm{cc})$. The volume $100 \mathrm{~mL}$ gives high recovery $(84.57 \%)$ but still less than the recovery obtained by $250 \mathrm{~mL}(87.53 \%)$. However, $250 \mathrm{~mL}$ was selected to the next experiments for further considerations.

Figure $1 \mathrm{~b}$ shows that three different volumes of methanol $(0.25,0.50$ and $1.00 \mathrm{~mL})$ were tested as reconstitution solvent after solid phase extraction loading. Highest recovery was obtained at $79.12 \%$ by using $0.25 \mathrm{~mL}$ of methanol as reconstitute solvent. Other volumes gave recovery at $72.03 \%(1 \mathrm{~mL} \mathrm{MeOH})$ and $71.66 \%(0.5 \mathrm{~mL}$ $\mathrm{MeOH})$ which were not significantly different, more explanations in the next section. From these results, $0.25 \mathrm{~mL}$ reconstitute volume was selected for further experiments.

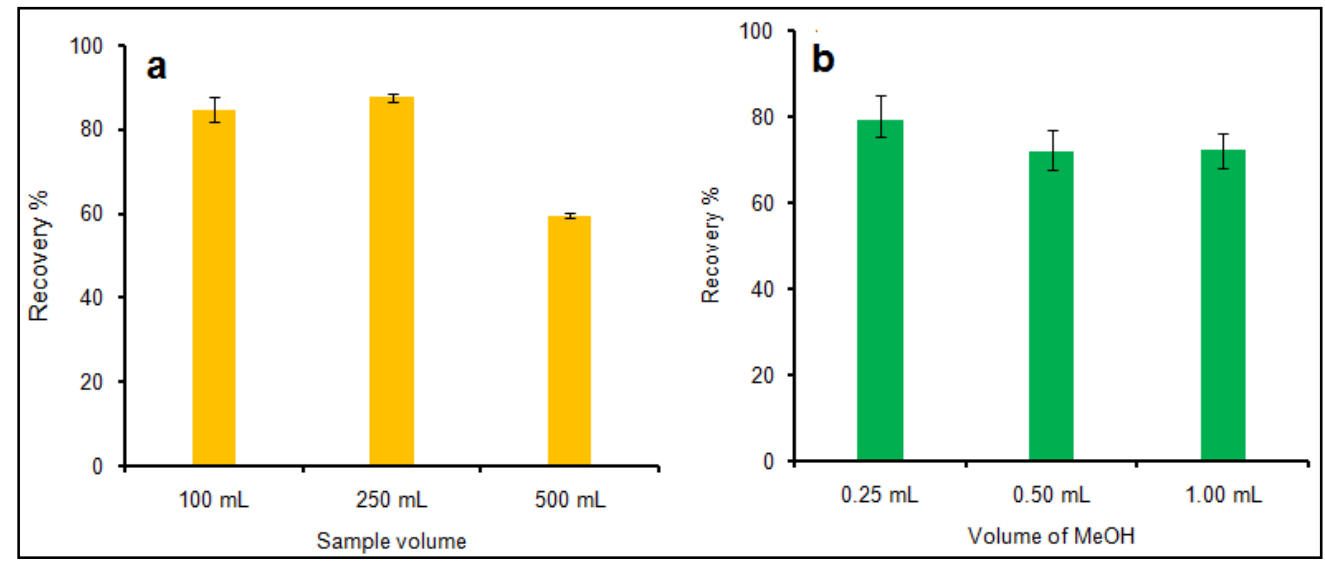

Figure 1. Effect of (a) sample volume, and (b) volume of solvent on the recovery of caffeine

\section{Effect of mobile phase and wavelength}

In this study, the isocratic elution program was used for seven mobile phases (100\% $\mathrm{MeOH}$ (S1), DIW:MeOH (20:80) (S2), DIW:MeOH (40:60) (S3), DIW:MeOH (60:40) (S4), DIW:MeOH (80:20) (S5), 100\% DIW (S6), ACN:MeOH (40:60) (S7)) as presented in Figure 2. Four mobile phases were presented because the others exhibited very low signal or not detected so they were excluded from the graph. However, the mobile phase chosen for analytical method validation was $100 \% \mathrm{MeOH}$, presented a mobile phase holdup time of 0.652 min and good separation as shown in Table 2.

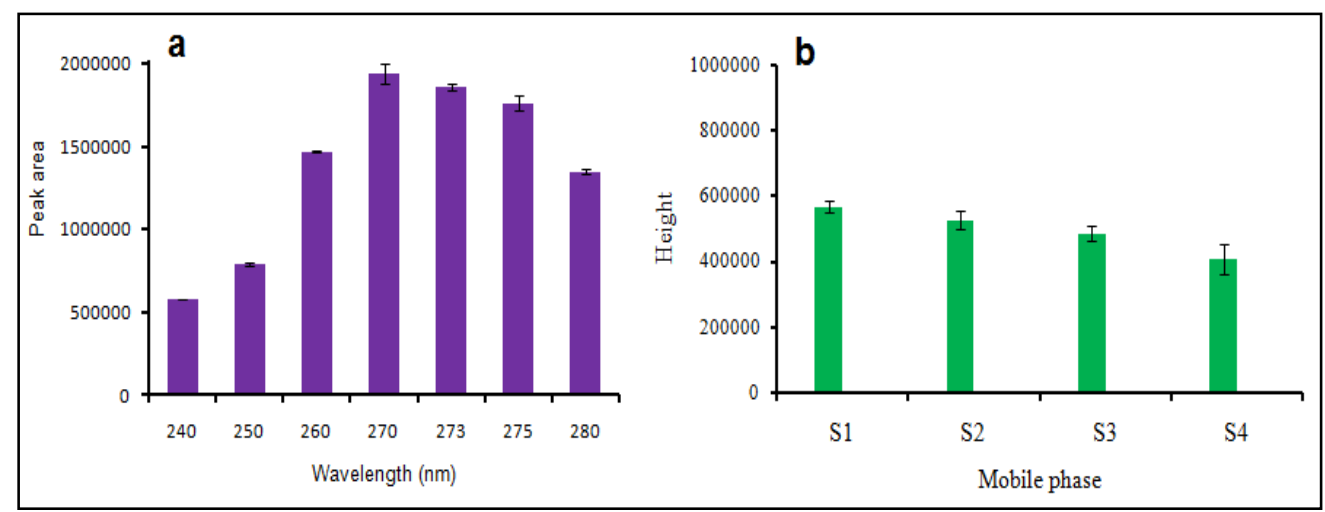

Figure 2. Effect of (a) wavelength, and (b) mobile phase on the sensitivity of caffeine analysis 
Mobile phase ACN:MeOH (40:60) (S7) exhibited very low peak signal (peak area 8743 and peak height 2469) which means an additional of acetonitrile reduce the efficiency of elution for caffeine (data not shown). In case of mobile phase $(100 \%$ DIW) no peak was obtained, may be this was attributed to the very low polarity of this mobile phases to be suitable for elution of caffeine. Consequently, the mobile phases DIW:MeOH (20:80) (S2), DIW:MeOH (40:60) (S3), DIW:MeOH (60:40) (S4) produced less peak height sequentially. From these results, increasing the amount of water in the mobile phase has led to low peak height and broad peak which are not good in terms of separation using high performance liquid chromatography.

Wavelength was another parameter considered in this study using HPLC instrument equipped with ultra-violet (UV) detector. Optimization of wavelength is very important because the targeted compound has optimum absorbance on its own wavelength. The optimum of chromatographic signal response was obtained at $270 \mathrm{~nm}$. At this wavelength, caffeine signal response was obtained with maximum peak area which was observed at $1940353.25 \mu \mathrm{V} / \mathrm{s}$.

Wavelength was optimised at 240,250,260,270, 273, 275 and $280 \mathrm{~nm}$. At $270 \mathrm{~nm}$, the concentration of caffeine was the highest compared to the rest of the wavelengths. The peak area of caffeine was influenced by the wavelength but the retention time and the shape were not influenced. Wavelength was not responsible for elution of caffeine from column, but it only affected the absorbance. However, a significant difference was observed at all the wavelengths except at 270, 273 and $275 \mathrm{~nm}$.

\section{Method performance}

Analytical performances namely linearity, repeatability, robustness, detection limit and quantification limit were tested and presented in Table 2 and 3, respectively. Good linearity was obtained by plotting external calibration of a series of caffeine standard solution $(\mathrm{n}=11)$. Regression equation was expressed as $y=13273 x+46610$ with regression coefficient $\mathrm{R}^{2}=0.995$. Repeatability of the developed method was tested using intra and inter-day precision at 3 level concentrations $(50,100,200 \mathrm{mg} / \mathrm{L})$. Analysis of results indicated that repeatability of developed method was precise with RSD value $<3.29 \%$, which explained good routine work. Limit of detection and quantification were calculated at $\mathrm{LOD}=0.066 \mu \mathrm{g} / \mathrm{L}$ and $\mathrm{LOQ}=0.20 \mu \mathrm{g} / \mathrm{L}$ respectively. Robustness test was performed on volume injection and flow rate of mobile phase. The results showed that the method is robust. Relative standard deviation for both effect of volume injection and flow rate ranged from $3.50 \%$ to $1.95 \%$ respectively.

Table 2. Precision of SPE method on caffeine analysis

\begin{tabular}{lcccc}
\hline $\begin{array}{l}\text { Concentration } \\
(\mathbf{m g} / \mathbf{L})\end{array}$ & \multicolumn{2}{c}{$\begin{array}{c}\text { Intra-day } \\
(\mathbf{n}=\mathbf{9})\end{array}$} & \multicolumn{2}{c}{$\begin{array}{c}\text { Inter-day } \\
(\mathbf{n}=\mathbf{1 8})\end{array}$} \\
\hline & Concentration \pm SD & $\mathbf{R t} \pm$ SD & Peak Area \pm SD & $\mathbf{R t} \pm$ SD \\
\hline 50 & $50.36 \pm 0.115$ & $0.652 \pm 0.002$ & $49.84 \pm 0.224$ & $0.652 \pm 0.001$ \\
100 & $99.5 \pm 7.662$ & $0.652 \pm 0.001$ & $100.5 \pm 0.603$ & $0.654 \pm 0.002$ \\
200 & $198.74 \pm 2.027$ & $0.652 \pm 0.001$ & $192.05 \pm 1.108$ & $0.652 \pm 0.001$ \\
\hline
\end{tabular}

Table 3. Robustness test on HPLC performance for caffeine analysis $(n=3)$

\begin{tabular}{lccc}
\hline Variable & Level & Peak Area \pm SD & Rt \pm SD \\
\hline Volume injection $(\mu \mathrm{L})$ & 20 & $50.9 \pm 0.186$ & $0.652 \pm 0.001$ \\
& 21 & $53.8 \pm 0.078$ & $0.651 \pm 0$ \\
& 22 & $55.22 \pm 0.138$ & $0.652 \pm 0$ \\
Flow rate of mobile phase $(\mathrm{mL} / \mathrm{min})$ & 0.30 & $52.45 \pm 0.488$ & $0.651 \pm 0.001$ \\
& 0.31 & $51.02 \pm 0.209$ & $0.632 \pm 0$ \\
& 0.32 & $48.34 \pm 0.247$ & $0.615 \pm 0.001$ \\
\hline
\end{tabular}




\section{Statistical analysis}

The most significant results were obtained with volume of $\mathrm{MeOH}$ as reconstitute solvent, volume of sample, mobile phase composition and wavelength of caffeine absorbance. The significance value in terms of $\mathrm{P}$-value was 0.000 in all cases which means high significant results were obtained. In case of volume used for $\mathrm{MeOH}$, three volumes $(0.25,0.50$ and $1.00 \mathrm{~mL})$ were tested by one-way ANOVA. An amount 0.50 and $1.00 \mathrm{~mL}$ volumes were shared with same letter B means it was not significant but both volumes were significantly different from $0.25 \mathrm{~mL}$ volume.

Table 4. Statistical analysis of variance for the different independent factors using Tukey method and $95 \%$ confidence, $P$ value less than 0.05 .

\begin{tabular}{|c|c|c|c|c|c|c|}
\hline \multicolumn{7}{|c|}{ Volume of MeOH as Reconstitute Solvent } \\
\hline Factor Value & $\mathbf{N}$ & Mean or Recovery & & & Grouping & \\
\hline 0.25 & 3 & 79.073 & A & & & \\
\hline 0.50 & 3 & 71.660 & & B & & \\
\hline 1.00 & 3 & 71.337 & & B & & \\
\hline \multicolumn{7}{|c|}{ Sample Volume } \\
\hline Factor Value & $\mathbf{N}$ & Mean of Recovery & & & Grouping & \\
\hline 250 & 3 & 87.53 & A & & & \\
\hline 100 & 3 & 84.57 & & B & & \\
\hline 500 & 3 & 59.50 & & & $\mathrm{C}$ & \\
\hline \multicolumn{7}{|c|}{ Mobile Phase Composition } \\
\hline Factor Symbol & $\mathbf{N}$ & Mean of Peak Area & & & Grouping & \\
\hline S1 & 4 & 565263 & A & & & \\
\hline $\mathrm{S} 2$ & 4 & 526415 & A & B & & \\
\hline $\mathrm{S} 3$ & 4 & 484833 & & B & & \\
\hline S4 & 4 & 406861 & & & $\mathrm{C}$ & \\
\hline S7 & 2 & 2469 & & & $\mathrm{D}$ & \\
\hline S5 & 4 & 462 & & & $\mathrm{D}$ & \\
\hline \multicolumn{7}{|c|}{ Wavelength of Caffeine } \\
\hline Factor Value & $\mathbf{N}$ & Mean of Peak Area & & & Grouping & \\
\hline 270 & 4 & 1940353 & $\mathrm{~A}$ & & & \\
\hline 273 & 4 & 1863330 & & B & & \\
\hline 275 & 4 & 1764819 & & & $\mathrm{C}$ & \\
\hline 260 & 4 & 1470816 & & & $\mathrm{D}$ & \\
\hline 280 & 4 & 1348010 & & & $\mathrm{E}$ & \\
\hline 250 & 4 & 791823 & & & & $\mathrm{~F}$ \\
\hline 240 & 4 & 580249 & & & & G \\
\hline
\end{tabular}

Sample volume was statistically tested and exhibited very high significant difference in terms of peak area. The sample volumes $(100,250$ and $500 \mathrm{~mL})$ were totally statistically different as shown in Table 4. Sample volume (100 $\mathrm{mL}$ ) was selected as the best sample volume because of its highest recovery. Mobile phase composition was also investigated statistically. However, mobile phase S1 and S2 were not differed significantly since both of them were 
represented by letter A. Furthermore, the mobile phases S2 and S3, and S5 and S7 were not differed significantly. Mobile phase S4 was only significantly different from other mobile phases. Based on all these results, Methanol, $\mathrm{S} 1$, was selected as the best solvent because it produced sharp peak and well separated. Finally, seven mobile phases were tested to investigate the significance. All wavelengths were significantly different (all different letters) as shown in Table 4 . The wavelength $270 \mathrm{~nm}$ was selected as the best wavelength based on its peak height.

\section{Analysis of real samples}

Analysis of caffeine residue in surface water was successfully carried out. Level of concentration was recorded within the range of 31.7 to $50.1 \mu \mathrm{g} / \mathrm{L}$. The highest concentration was $50.1 \mu \mathrm{g} / \mathrm{L}$ recorded at $\mathrm{S} 5$ drainage nearby UKM's mosque (downstream) and the lowest concentration was $31.7 \mu \mathrm{g} / \mathrm{L}$ which was $\mathrm{S} 1$ nearby cafeteria (upstream). The concentration of caffeine at other stations were recorded $34.7 \mu \mathrm{g} / \mathrm{L}$ (S2) after cafeteria, $43.1 \mu \mathrm{g} / \mathrm{L}$ (S3) and $44.6 \mu \mathrm{g} / \mathrm{L}$ (S4). The results suggested that flushing from upstream to downstream as well as the discharge of water mixed with the tea beverages as the major factors for contribution the occurrence of caffeine in surface water. The increasing of caffeine gradually from S1 to S5 was not surprising because the number of sources increased as well in the same line. Finally, the site S5 was considered as the meeting point for all these sources thus it exhibited the highest concentration of caffeine. All results were tested statistically and showed a significant different among all sites as shown in Figure 3. The chromatogram peak of caffeine residue detected in water samples is presented in Figure 4.

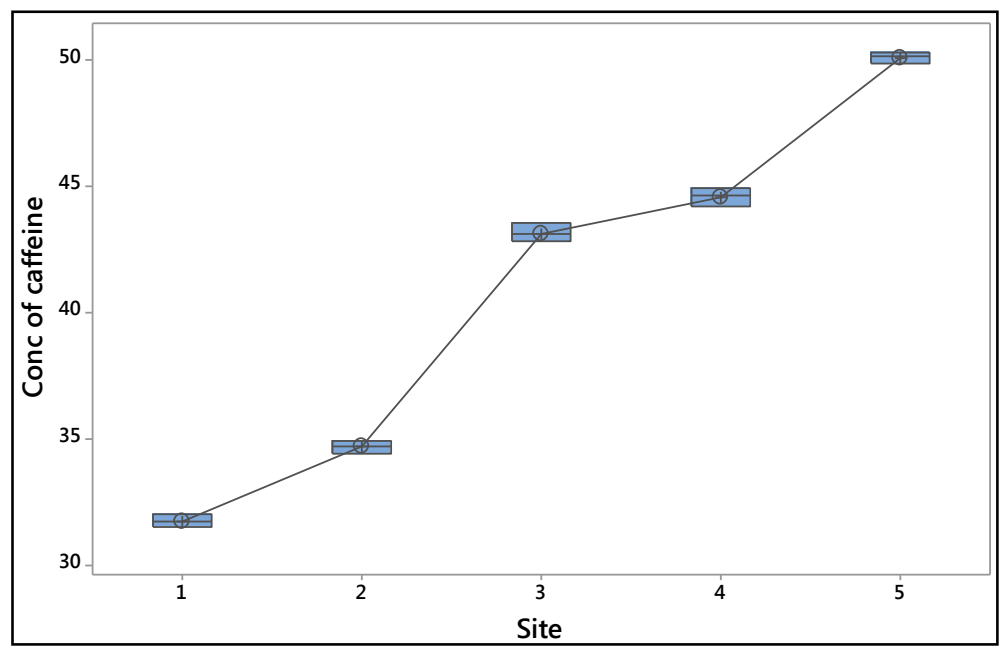

Figure 3. Box plot of the concentration of caffeine against sampling sites at $95 \%$ confidence interval and P-value 0.05

\section{TOF screening and confirmation}

For selection of the MS ionization mode, a standard solution of caffeine in 1:9 $\mathrm{MeOH}-\mathrm{H}_{2} \mathrm{O}$ was separated and analyzed by LC-TOF/MS. The MS was tuned for $[\mathrm{M}+\mathrm{H}]^{+}$ions in the ESI $(+)$ionization mode and for $[\mathrm{M}-\mathrm{H}]^{-}$ions in the ESI (-) modes. The positive ionization mode was preferred for caffeine. Caffeine was not detected in the negative ionization mode. TOF/MS was selected as a better solution to confirm that caffeine was present in surface water (one sample was selected). The $\mathrm{m} / \mathrm{z}$ of the caffeine was extracted from the total ionic chromatogram (TIC) in positive ionization mode as proton adduct $[\mathrm{M}+\mathrm{H}]^{+}$with $0.2 \mathrm{ppm}$ mass error through Bruker Daltonics DataAnalysis software as shown in Figure 5. To increase the selectivity of TOF measurements, a narrow accurate mass interval was used to reconstruct the chromatographic traces. Extracted ion chromatogram (EIC) was typically extracted using Bruker Daltonic software with $20 \mathrm{mDa}$ mass window for caffeine in water sample. 


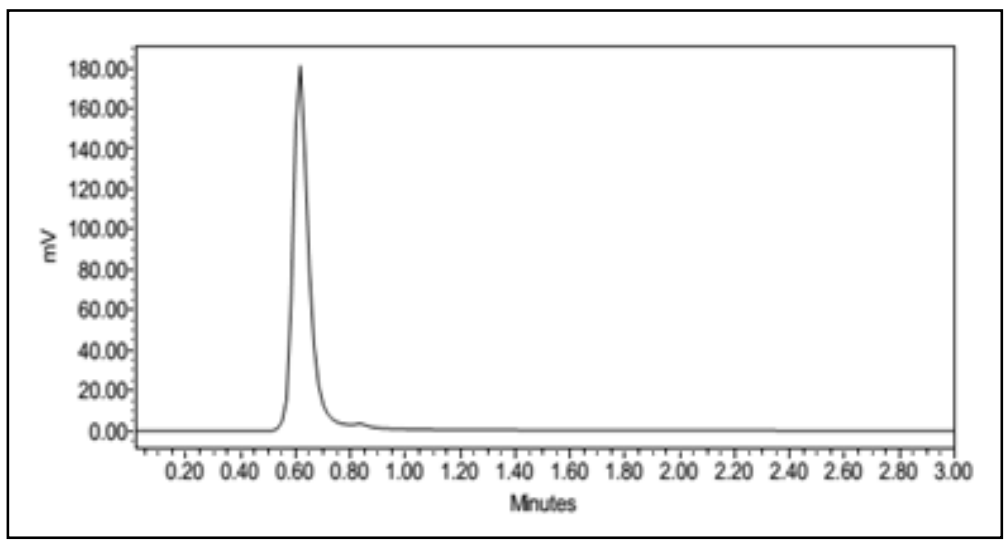

Figure 4. Signal response of caffeine residue traced in surface water by HPLC

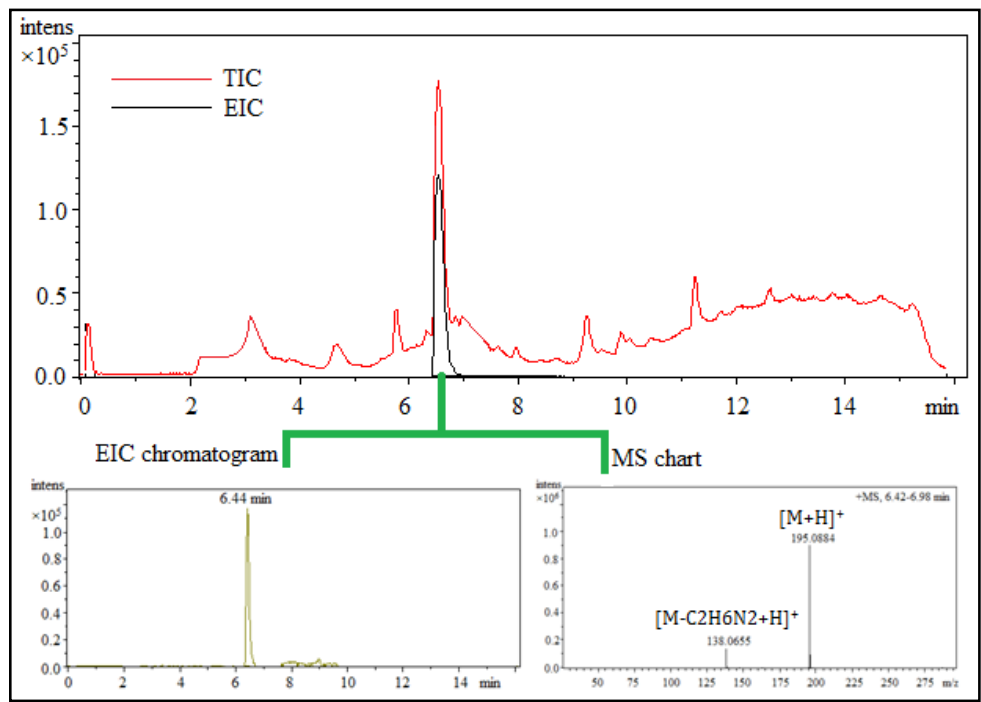

Figure 5. Confirmation profile for caffeine in surface water using LC-TOF/MS

\section{Conclusion}

The optimization results showed that the HPLC developed method presented here can be considered reliable for the determination of caffeine residue in surface water. Good validation results were obtained in terms of linearity, precision, sensitivity and robustness on method extraction and HPLC performances. An application of the developed method on real samples showed that the occurrence of caffeine residue could reach to $\mu \mathrm{g} / \mathrm{L}$ level of concentrations.

\section{Acknowledgement}

This study has been funded by Research University Grants UKM-DLP-2012-024, UKM-AP-2011-21, BKP-FSTK001671 and FRGS-1-2013-ST01-UKM-01-1. Authors are thankful to ALIR staff for facilities assistance during research activities. 


\section{References}

1. Ferreira, A. P., de Lourdes, C. and da Cunha, N. (2005). Anthropic pollution in aquatic environment: Development of a caffeine indicator. International Journal of Environmental Health Research, 15: 303 - 311.

2. Buerge, I. J., Poiger, T., Müller, M. D. and Buser, H. R. (2003). Caffeine, an anthropogenic marker for wastewater contamination of surface waters. Environmental Science \& Technology, 37: 691 - 700.

3. Gardinali, P. R. and Zhao, X. (2002). Trace determination of caffeine in surface water samples by liquid chromatography-atmospheric pressure chemical ionization-mass spectrometry (LC-APCI-MS). Environment International, 28: $521-528$.

4. Barrett, M. H., Hiscock, K. M., Pedley, S., Lerner, D. N., Tellam, J. H. and French, M. J. (1999). Marker species for identifying urban groundwater recharge sources: a review and case study in Nottingham, UK. Water Research, 33: 3083 - 3097.

5. Chen, Z., Pavelic, P., Dillon, P. and Naidu, R. (2002). Determination of caffeine as a tracer of sewage effluent in natural waters by on-line solid-phase extraction and liquid chromatography with diode-array detection. Water Research, 36: 4830 - 4838.

6. Seiler, R. L., Zaugg, S. D., Thomas, J. M. and Howcroft, D. L. (1999). Caffeine and pharmaceuticals as indicators of waste water contamination in wells. Groundwater, 37: $405-410$.

7. Lacina, P., Mravcová, L. and Vávrová, M. (2013). Application of comprehensive two-dimensional gas chromatography with mass spectrometric detection for the analysis of selected drug residues in wastewater and surface water. Journal of Environmental Sciences, 25: $204-212$.

8. Al-Qaim, F. F., Abdullah, M. P., Othman, M. R., Mussa, Z. H., Zakaria, Z., Latip, J. and Afiq, W. M. (2015). Investigation of the environmental transport of human pharmaceuticals to surface water: A case study of persistence of pharmaceuticals in effluent of sewage treatment plants and hospitals in Malaysia. Journal of the Brazilian Chemical Society, 26: $1124-1135$.

9. Mompelat, S., Le Bo, B. and Thomas, O. (2009). Occurrence and fate of pharmaceutical products and byproducts, from resource to drinking water. Environment International, 35: 803 - 814.

10. Gibson, A. M., Morgan, R. M., MacDonald, N. and Nikitin, A. G. (2012). Possible effects of the presence of common household chemicals in the environment: the growth of an aquatic bacterial species on high concentrations of caffeine. Journal of Biotech Research, 4: $72-79$.

11. Al-Qaim, F. F., Mussa, Z. H., Othman, M. R. and Abdullah, M. P. (2015). Removal of caffeine from aqueous solution by indirect electrochemical oxidation using a graphite-PVC composite electrode: A role of hypochlorite ion as an oxidising agent. Journal of Hazardous Materials, 300: 387 - 397.

12. Al-Qaim, F. F., Abdullah, M. P. and Othman, M. R. (2012). Analysis of different therapeutic classes using liquid chromatography-mass spectrometry in the aquatic environment: A review. International Journal of Pharmacy and Pharmaceutical Sciences, 4: $3-11$.

13. Mohamed, F. F., Abdullah, M. P., Othman, M. R. and Zakeria, Z. B. (2012). SPE-LC-Mass spectrometry analysis for basic pharmaceuticals with different therapeutic classes in aquatic environment. Journal of Applied Sciences Research, 8: 2124 - 2132.

14. Moeder, M., Schrader, S., Winkler, M. and Popp, P. (2000). Solid-phase microextraction-gas chromatographymass spectrometry of biologically active substances in water samples. Journal of Chromatography A, 873: 95 106.

15. Werres, F., Stien, J., Balsaa, P., Schneider, A., Winterhalter, P. and Overath, H. (2000). Automatisierte Bestimmung polarer Arzneimittelrückstände in Wässern mittels Festphasenmikroextraktion (SPME) und Derivatisierung. Vom Wasser, 94: 135 - 147.

16. Rasmussen, K. E. and Pedersen-Bjergaard, S. (2004). Developments in hollow fibre-based, liquid-phase microextraction. TrAC Trends in Analytical Chemistry, 23: 1 - 10.

17. Al-Qaim, F. F., Abdullah, M. P., Othman, M. R., Latip, J. and Zakaria, Z. (2014). Multi-residue analytical methodology-based liquid chromatography-time-of-flight-mass spectrometry for the analysis of pharmaceutical residues in surface water and effluents from sewage treatment plants and hospitals. Journal of Chromatography A, 1345: $139-153$.

18. Verenitch, S. S., Lowe, C. J. and Mazumder, A. (2006). Determination of acidic drugs and caffeine in municipal wastewaters and receiving waters by gas chromatography-ion trap tandem mass spectrometry. Journal of Chromatography A, 1116: 193 - 203. 
19. Gomes, P. C. L., Barnes, B. B., Santos-Neto, A. J., Lancas, F. M. and Snow, N. H. (2013). Determination of steroids, caffeine and methylparaben in water using solid phase microextraction-comprehensive twodimensional gas chromatography-time of flight mass spectrometry. Journal of Chromatography A, 1299: 126 130.

20. Alvi, S. N., and Muhammad M. H. (2011). Validated HPLC method for determination of caffeine level in human plasma using synthetic plasma: Application to bioavailability studies. Journal of Chromatographic Science, 49: $292-296$.

21. Chowdhury, S. R., Maleque, M., and Shihan, M. H. (2012). Development and validation of a simple RP-HPLC method for determination of caffeine in pharmaceutical dosage forms. Asian Journal of Pharmaceutical Analysis, 2: $1-4$. 